\title{
Analisis Scanning Electron Microscope (SEM) Mikroarsitektur Daerah Metafisis Os Femur Tikus Putih (Rattus novergicus) Ovariohisterektomi dengan Pemberian Madu Lebah (Apis dorsata) Hutan Sumbawa
}

\section{Analysis of Scanning Electron Microscope (SEM) Microarchitecture of Metaphysical Os Femur in Ovariohysterectomized rats with Honey Bees Sumbawa Forest (Apis dorsata)}

\author{
Samsi Yordan ${ }^{1}$, Abdullah Hasib ${ }^{1}$, Muhammad Huda Ramadhan Ibrahim ${ }^{2}$, Siti Nur Rohmah ${ }^{1}$, \\ Salsabilla Abani ${ }^{1}$, Ira Sari Yudaniayanti ${ }^{2^{*}}$ \\ ${ }^{1}$ Fakultas Kedokteran Hewan, Universitas Airlangga, Surabaya, 60115, Indonesia \\ ${ }^{2}$ Departemen Klinik, Fakultas Kedokteran Hewan, Universitas Airlangga, Surabaya, 60115, Indonesia \\ *Email : irasari.vet@gmail.com \\ Naskah diterima : 9 Agustus 2017, direvisi : 27 Februari 2018, disetujui : 30 Mei 2018
}

\begin{abstract}
The aims of this study was to determine the effect of honey bees (Apis dorsata) to prevent the decrease of femur density in ovariohysterctomized rats as animal model of osteoporosis by Scanning Electron Microscope (SEM). This study used 20 adult female white rats (Rattus norvegicus) with body weight 300 gr. Divided into 5 groups, negative control group ( $\mathrm{P} 0-)$, sham operated rat given aquadest $1.5 \mathrm{ml} /$ day ; Positive control group $(\mathrm{P} 0+)$, in ovariohysterectomized rat given aquadest $1.5 \mathrm{ml} /$ day; Treatment group $1(\mathrm{P} 1)$, ovariohysterectomized rat and given honey 1 gram $/ \mathrm{kg} \mathrm{BB}+1.5 \mathrm{ml}$ aquadest; Treatment group $2(\mathrm{P} 2)$,ovariohysterectomized rat and given honey 2 grams / $\mathrm{kg} \mathrm{BB}+1.5 \mathrm{ml}$ aquadest; Treatment group 3 (P3), ovariohysterectomized rat and given honey 4 grams $/ \mathrm{kg} \mathrm{BB}+1.5 \mathrm{ml}$ aquadest. After 12 weeks, all rats were sacrified for removal of the femur and performed by SEM. Analysis of SEM showed that rats administered honey with a dose of 4 grams / $\mathrm{kg} \mathrm{BW}$ (P3) showed bone density approaching negative control treatment ( $\mathrm{P} 0-)$, ie, ovariohysterectomized rats. $\mathrm{P} 3$ showed the most less bone porosity than other treatment groups. The largest and most uniformly distributed porosity was shown by the positive control group $(\mathrm{P} 0+)$. The best results with the smallest quantity and size of the porosity of femur is in P3 group. In conclusion, honey (Apis dorsata) can prevent the decrease in bone density of the femur by Scanning Electron Microscope (SEM).
\end{abstract}

Key words : Honey, Osteoporosis, Scanning Electron Microscope.

\begin{abstract}
Abstrak
Penelitian ini bertujuan untuk mengetahui pengaruh pemberian madu lebah (Apis dorsata) dalam mencegah terjadinya penurunan kepadatan tulang femur tikus putih ovariohisterektomi yang dilihat menggunakan Scanning Electrone Microscope (SEM). Penelitian ini menggunakan 20 ekor tikus putih betina (Rattus norvegicus) dewasa berat badan 300 gr, dan terbagi menjadi 5 kelompok, yaitu kelompok kontrol negatif / sham operated (P0-), tidak dilakukan ovariohisterektomi dan hanya diberi aquadest 1,5 $\mathrm{ml} /$ hari; kelompok kontrol positif (P0+), dilakukan ovariohisterektomi dan hanya diberi aquadest $1,5 \mathrm{ml} /$ hari; kelompok perlakuan 1 (P1), dilakukan ovariohisterektomi dan diberi madu dengan dosis 1 gram $/ \mathrm{kg} \mathrm{BB}+1,5 \mathrm{ml}$ aquadest; kelompok perlakuan 2 (P2), dilakukan ovariohisterektomi dan diberi madu dengan dosis 2 gram $/ \mathrm{kg} \mathrm{BB}+1,5 \mathrm{ml}$ aquadest; kelompok perlakuan 3 (P3), dilakukan ovariohisterektomi dan diberi madu dengan dosis 4 gram $/ \mathrm{kg} \mathrm{BB}+1,5 \mathrm{ml}$ aquadest. Setelah $12 \mathrm{minggu}$, semua tikus dikorbankan untuk pengangkatan tulang femur dan dilakukan evaluasi SEM. Hasil pemeriksaan SEM menunjukkan tikus yang dilakukan pemberian madu dengan dosis 4 gram $/ \mathrm{kg}$ BB (P3) menunjukkan kepadatan tulang yang mendekati perlakuan kontrol negatif( $\mathrm{P} 0-$ ), yaitu tikus yang tidak dilakukan ovariohisterektomi. P3 menunjukkan hasil porositas tulang yang lebih kecil dibanding kelompok perlakuan lain. Porositas tulang terbanyak dan tersebar merata ditunjukkan oleh kelompok kontrol postif $(\mathrm{P} 0+)$. Hasil terbaik dengan jumlah dan ukuran porositas tulang femur terkecil terdapat pada kelompok P3. Berdasarkan hasil penelitian ini dapat disimpulkan bahwa madu lebah (Apis dorsata) dapat mencegah penurunan kepadatan tulang femur yang dilihat menggunakan Scanning Electron Microscope (SEM).
\end{abstract}

Kata kunci: Madu, Osteoporosis, Scanning Electron Microscope. 


\section{Pendahuluan}

Osteoporosis atau keropos tulang adalah penyakit kronik yang ditandai dengan pengurangan massa tulang yang disertai kemunduran mikroarsitektur tulang sehingga terjadi penurunan kualitas jaringan tulang yang dapat menimbulkan kerapuhan tulang (Utomo dkk, 2010). Osteoporosis dipengaruhi oleh beberapa hal, antara lain wanita, usia, ras/suku, serta keturunan. Faktor utama yang menyebabkan osteoporosis adalah penurunan hormon estrogen (Matthai et al., 2001). Seorang perempuan atau hewan betina yang mengalami ovariohisterektomi akan mengalami gejala menopause karena terjadi penurunan hormon estrogen. Sehingga pembentukan osteoblast terhambat dan osteoklast meningkat yang mengakibatkan kerusakan tulang lebih cepat dibandingkan pembentukan tulang, hal ini akan mempercepat terjadinya osteoporosis (Afiyah, 2010).

Sampai saat ini, pengobatan utama osteoporosis adalah Hormone Replacement Therapy (HRT) dan bifosfonat. HRT yang berisi estrogen telah terbukti mengurangi berbagai macam fraktur, seperti pada pergelangan tangan, tulang belakang dan semua patah tulang nonvertebral. Efek HRT dikenal dapat meningkatkan tingkat hormon seks dan meningkatkan massa tulang dengan sangat efektif. Risiko penggunaan HRT yang paling utama dapat menimbulkan kanker payudara. Estrogen dapat meningkatkan laju proliferasi sel di jaringan kelenjar payudara dan bisa berpotensi bertindak baik dalam inisiasi dan promosi kanker payudara (Utomo dkk, 2010). Penanganan osteoporosis yang lain diberikan suplemen kalsium dan vitamin $\mathrm{D}$, juga protein. Penderita osteoporosis biasanya membutuhkan beberapa jenis obat yang harus dikonsumsi terusmenerus untuk mempertahankan tulang yang sehat, yaitu obat untuk membangun tulang, membuat tulang menjadi makin padat, serta menghambat proses pengeroposan. Obat-obat ini antara lain golongan bifosfonat, raloxifene, kalsitonin, dan tibolone (Syam dkk, 2014), namun demikian obat tersebut dapat menimbulkan banyak efek samping seperti nyeri lambung, terutama apabila cara minum obat tidak sesuai, perubahan metabolisme lemak dan dapat mengakibatkan defisiensi estrogen (Rachman, 2004).

Berdasarkan permasalahan yang muncul akibat penggunaan obat kimia yang terus menerus, maka dicari alternatif lain dengan resiko yang lebih kecil, yaitu pemanfaatan bahan alam. Madu merupakan salah satu bahan alam yang mempunyai potensi sebagai antiosteoporosis. Menurut penelitian Zaid, et al.(2010) madu mengandung sekitar 200 zatzat seperti campuran gula (fruktosa, glukosa, maltosa dan sukrosa), sejumlah kecil konstituen lain seperti mineral, protein, vitamin, asam organik, flavonoid, asam fenolik, enzim dan phytochemical lainnya. Beberapa kandungan nutrisi lain dalam madu seperti yang tersebut diatas ikut berperan dalam menunjang perkembangan tulang (Jaya, 2011).

Madu adalah produk lebah alami dikenal dengan kandungan fitokimia cukup tinggi (senyawa fenolik atau polifenol yang berkontribusi terhadap efek fisiologis positif). Madu kaya akan antioksidan, seperti flavonoid dan asam fenolat. Flavonols pada madu akan berinteraksi secara langsung dengan esterogen melalui reseptor ER- $\beta$ dan ER- $\alpha$, kandungan asam glukonat yang dapat meningkatkan absorbsi kalsium di dalam usus. Quarticetin dan kaempferol dapat menginduksi apoptosis osteoklas dewasa sehingga menghambat resorbsi tulang dan reactive oxygen species intraseluler dalam osteoklas oleh mekanisme estrogen (Sarah, et al., 2012). Mekanisme lain yang dilakukan oleh madu adalah penurunan $\mathrm{pH}$ lumen usus oleh asam glukonat. Penurunan $\mathrm{pH}$ lumen menyebabkan peningkatan penyerapan kalsium dalam usus (Zaid, et al., 2010). Indonesia telah diketahui mempunyai spesies lebah madu terbanyak di dunia. Salah satu variasi spesies lebah madu adalah Apis dorsata. Apis dorsata dapat 
ditemukan hampir di seluruh kepulauan di Indonesia kecuali Maluku dan Irian Jaya. Kekayaan Indonesia akan jenis lebah madu tidak diragukan lagi (Hadisoesilo, 2001).

Berdasarkan kedua hal tersebut maka madu mempunyai mempunyai potensi yang cukup bagus sebagai antiosteoporosis baik ditinjau dari kandungan bahan aktifnya maupun keberadaannya yang melimpah di Indonesia. Besarnya potensi madu yang dapat meningkatkan kepadatan tulang, serta ketersediaan bahan yang memiliki potensi antiosteoporosis, maka dapat dilakukan suatu kajian di jenjang penelitian antara potensi madu sebagai antiosteoporosis terhadap tulang femur tikus putih ovariohisterektomi yang dianalisis menggunakan Scanning Electron Microscope (SEM).

Tujuan dari penelitian ini adalah untuk mengetahui efek madu lebah (Apis dorsata) dalam mencegah terjadinya penurunan kepadatan tulang femur tikus putih ovariohisterektomi yang dilihat menggunakan Scanning Electron Microscope (SEM).

Hipotesis penelitian ini adalah madu lebah (Apis dorsata) dapat mencegah terjadinya penurunan kepadatan tulang femur tikus putih ovariohisterektomi dengan analisis Scanning Electron Microscope (SEM).

\section{Materi dan Metode Penelitian}

Penelitian ini dilakukan di Ruang Operasi Rumah Sakit Hewan Universitas Airlangga, Laboratorium Karakterisasi Material Karakterisasi, Fakultas Teknologi Industri Institut Teknologi Sepuluh November (ITS), kandang hewan coba Fakultas Kedokteran Hewan Universitas Airlangga. Penelitian ini dilakukan selama 5 bulan.

Sejumlah 20 ekor tikus putih (Rattus norvegicus) betina dewasa, dengan berat badan kurang lebih 300 gram dibagi dalam 5 kelompok secara rambang. setiap 3 ekor tikus ditempatkan dalam kandang plastik dengan ukuran $40 \mathrm{~cm}$ X $30 \mathrm{~cm}$. Setiap tikus diberi pakan dengan ransum $16 \%$ protein kasar dan $2657 \mathrm{Kcal} / \mathrm{Kg}$ ME yang dicampur dan digiling sehingga menghasilkan bentuk pellet di Laboratorium Pakan dan Gizi Fakultas Kedokteran Hewan Universitas Airlangga. Setiap tikus diberi air minum aquabidestilata secara ad libitum. Penelitian ini telah dinyatakan Laik Etik oleh "Animal Care and Use Committee" Fakultas Kedokteran Hewan Universitas Airlangga dengan nomor sertifikat “665-KE”.

Sampel madu dalam penelitian ini diperoleh dari hutan tropis Pulau Sumbawa Batulanteh. Madu diperoleh dari Jaringan Madu Hutan Indonesia dan dikonfirmasi untuk senyawa bioaktif yang terkandung di Unit Pelayanan Penilaian Fakultas Farmasi Universitas Airlangga dan lebah (Apis dorsata) penghasil madu dilakukan konfirmasi spesies di Laboratorium Entomologi Tropical Disease Centre Universitas Airlangga.

Berbagai macam obat yang digunakan pada penelitian ini antara lain Ketamil (ketamine $\mathrm{HCl}$, Ilium), Xyla (xylazine, Holland), Atropine Sulfas (PT. Ethica), Interflox (enrofloxacin).

Perlakuan dilaksanakan di Kandang Hewan Coba Fakultas Kedokteran Hewan Universitas Airlangga. Dua puluh tikus betina dewasa diadaptasikan selama 3 minggu, dibagi menjadi 5 kelompok, yaitu kelompok kontrol negatif ( $\mathrm{P} 0-$ ), tidak dilakukan ovariohisterektomi (Sham) dan diberi hanya aquadest 1,5 ml / hari / P0-; kelompok kontrol positif $(\mathrm{P} 0+)$, dilakukan ovariohisterektomi dan diberi hanya aquadest 1,5 $\mathrm{ml} /$ hari / $\mathrm{P} 0+$; kelompok perlakuan 1 (P1), dilakukan ovariohisterektomi dan diberi madu dengan dosis 1 gram $/ \mathrm{kg} \mathrm{BB}+$ aquadest 1,5 ml/hari/ P0; kelompok perlakuan 2 (P2), dilakukan ovariohisterektomi dan diberi madu dengan dosis 2 gram/kg BB + aquadest 1,5 ml/hari/ P0; kelompok perlakuan 3 (P3), dilakukan ovariohisterektomi dan diberi madu dengan dosis 4 gram $/ \mathrm{kg} \mathrm{BB}+$ aquadest $1,5 \mathrm{ml} / \mathrm{hari} / \mathrm{P} 0$. 
Prosedur ovariohisterektomi adalah sebagai berikut; pertama pembuatan sayatan pada $1 / 3$ caudal abdomen, yaitu ada garis tengah (linea mediana) yaitu tepat di belakang/posterior umbilikus ke arah kaudal. Panjang irisan dibuat secukupnya kira-kira 1-2 cm. Pertama kali penyayatan dilakukan pada kulit, subkutan, kemudian linea alba dan peritoneum. Setelah rongga abdomen terbuka dilakukan eksplorasi terhadap uterus menggunakan spay hook ke sepanjang dinding abdomen, setelah itu diputar ke arah medial untuk mendapatkan kornua uteri sebelah kanan dan ligamen-ligamen kemudian diangkat dari ruang abdomen. Selanjutnya ditelusuri kornua uteri yang didapatkan tadi sampai didapatkan ovarium. Ligamentum suspensori dipotong. Begitu ovarium kanan dan kiri ditemukan, bagian mesovarium dijepit dengan arteri klem kemudian diikat melingkar dengan kuat menggunakan benang. Dilakukan penjepitan dengan dua arteri klem di caudal, selanjutnya pemotongan dilakukan diantara kedua arteri klem tersebut. Membuat lubang pada ligamen di bagian caudal ovarium, kemudian pedikel ovarium proksimalis dijepit dengan arteri klem. Selanjutnya dibuat ikatan pada pedikel ovarium yang sudah di klem dengan menggunakan cut gut chromic 3.0 dan dilakukan pemotongan ligamen antara ikatan yang mengikat ligamen suspensori dengan klem yang menjepit ovarium. Setelah yakin tidak terjadi pendarahan, tang arteri yang mengikat ligamen suspensori bagian proksimal dapat dilepas. Bagian uterus ditelusuri sampai mencapai bifurkasio dan korpus uteri. Bagian korpus uteri dijepit dengan klem, kemudian dilanjutkan untuk menelusuri kornua uteri sisi lain. Dilakukan penjepitan dan pemotongan seperti sebelumnya. Mengangkat dua kornua uteri yang telah di potong tadi sampai didapatkan korpus uteri, dibuat lubang pada ligamen yang menggantung uterus serta arteri dan vena. Semua ligamen diklem hingga terjepit, dan dibuat ikatan yang kuat dan potong. Setelah yakin tidak terjadi pendarahan, klem yang menjepit uterus bagian proksimal dapat dilepas. Dilakukan reposisi pada uterus dan omentum ke dalam abdomen. Dengan menggunakan cut gut chromic 3.0 dilakukan penjahitan untuk menutup luka insisi. Lapisan peritonium dijahitkan dengan jahitan terputus sederhana menggunakan cat gut sedangkan kulit dijahit dengan pola matras silang menggunakan benang silk 3-0. Prosedur operasi ovariohisterektomi dilakukan anestesi menggunakan kombinasi ketamine $(50 \mathrm{mg} / \mathrm{kg} \mathrm{bb})$ dan xylazine (10 mg/kg bb) (Flecknell, 2009).

Dua hari setelah ovariohisterektomi mulai dilakukan pemberian madu dengan dosis 1 gram $/ \mathrm{kg}$ $\mathrm{BB}+1,5 \mathrm{ml}$ aquadest pada $\mathrm{P} 1, \mathrm{P} 2$ dengan dosis 2 gram $/ \mathrm{kg} \mathrm{BB}+1,5 \mathrm{ml}$ aquadest, $\mathrm{P} 3$ dengan dosis 4 gram $/ \mathrm{kg} \mathrm{BB}+1,5 \mathrm{ml}$ aquadest, sedang pada $\mathrm{P} 0+$ dan P0- hanya diberikan aquadest 1,5 $\mathrm{ml} /$ hari / P0. Masing masing perlakuan pada kelompok tersebut diberikan selama 12 minggu. . Pada akhir minggu ke 12, tikus dieuthanasi dengan ketamin dengan dosis $50 \mathrm{mg} / \mathrm{Kg}$ BB intraperitoneal (Yudaniayanti dkk., 2014). Dilakukan pembedahan pada bagian femur dan dilakukan pengangkatan os femur, kemudian dibersihkan dan disimpan dalam formalin 10\% untuk fiksasi jaringan. Satu hari berikutnya dilakukan pengamatan menggunakan SEM di Laboratorium Karakterisasi Material Karakterisasi, Fakultas Teknologi Industri, Institut Teknologi Sepuluh November (ITS).

\section{Hasil dan Pembahasan}

Pemeriksaan SEM dilakukan dua kali pengamatan, yaitu pada perbesaran 50x dan perbesaran 500x. Didapatkan hasil potongan melintang metafisis tulang femur tikus putih sebagai berikut : 

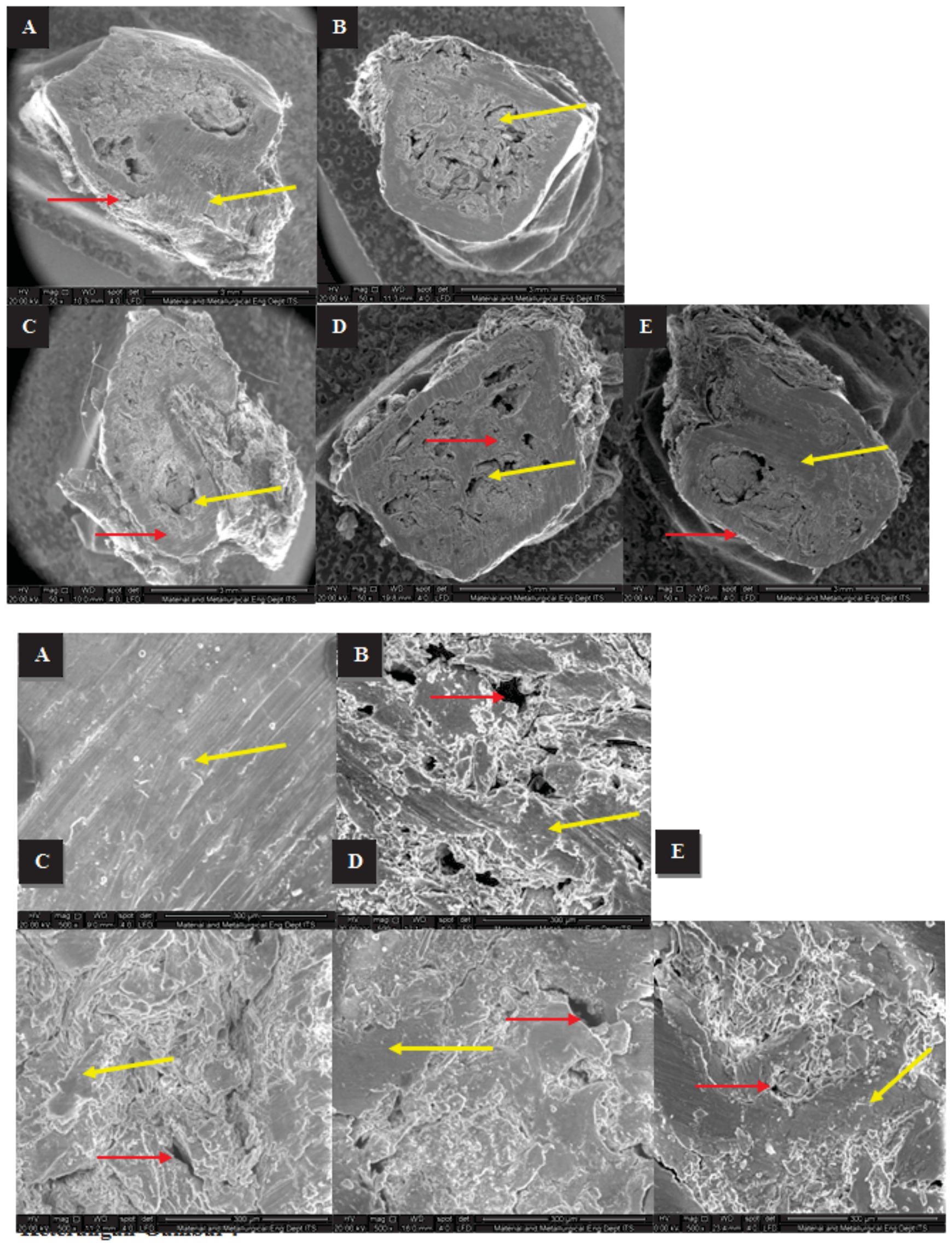

Gambar 1. Gambaran mikroarsitektur os femur tikus putih daerah metafisis pada kelima kelompok perlakuan (perbesaran 50x). 
1. Gambar A: merupakan kelompok kontrol negatif (P0-), yaitu kelompok tikus yang diberi aquadest 1,5 $\mathrm{ml}$ tanpa diovariohisterektomi. Menunjukkan gambaran tulang yang tidak memiliki porositas tulang sangat sedikit (tanda panah merah), hampir tidak menunjukkan porositas tulang dan menunjukkan gambaran tulang yang sangat padat (tanda panah kuning).

2. Gambar B : merupakan kelompok kontrol positif $(\mathrm{P} 0+)$, yaitu kelompok tikus yang diberi aquadest 1,5 $\mathrm{ml}$ dan diovariohisterektomi. Memberikan hasil gambaran tulang yang memiliki porositas terbanyak baik dilihat dengan perbesaran 50x ataupun 500x (tanda panah merah), sedikit tulang padat (tanda panah kuning).

3. Gambar C : merupakan kelompok perlakuan 1 (P1), diberi madu $1 \mathrm{~g} / \mathrm{kg} \mathrm{BB}+1,5 \mathrm{ml}$ aquadest dan diovariohisterektomi. Memberikan hasil gambaran Scanning Electron Microscope dengan masih terlihat porositas tulang yang lebih kecil (tanda panah merah) dari kelompok B dan masih terlihat tulang padat pada beberapa tempat (tanda panah kuning).

4. Gambar D : merupakan kelompok perlakuan 2 (P2), diberi madu $2 \mathrm{~g} / \mathrm{kg} \mathrm{BB}+1,5 \mathrm{ml}$ aquadest dan diovariohisterektomi. Menunjukkan hasil yang lebih baik dari kelompok B dan C. Porositas yang terlihat juga semakin sedikit dengan ukuran yang lebih kecil (tanda panah merah) dan daerah tulang padat lebih luas (tanda panah kuning).

5. Gambar E : merupakan kelompok perlakuan 3 (P3), diberi madu $4 \mathrm{~g} / \mathrm{kg} \mathrm{BB}+1,5 \mathrm{ml}$ aquadest dan diovariohisterektomi. Menunjukkan hasil yang mendekati kelompok A (kontrol negatif). Hasil Scanning Electron Microscope menunjukkan porositas tulang yang sangat sedikit (tanda panah merah) dengan kepadatan yang sangat baik (tanda panah kuning).
Berdasarkan hasil scanning electron microscope dapat dilihat bahwa tikus yang dilakukan pemberian madu dengan dosis 4 gram $/ \mathrm{kg}$ berat badan (P3) menunjukkan kepadatan tulang mendekati perlakuan sham operated atau (P0-). Porositas tulang P3 terlihat jumlahnya lebih sedikit daripada perlakuan lain. Porositas tulang terbanyak dan tersebar merata ditunjukkan oleh kelompok kontrol positif atau ( $\mathrm{P} 0+)$, dan berturut-turut kelompok ovariohisterektomi dengan dosis 1 (P1), dosis 2 (P2), dan dosis 3 (P3). Kelompok P1 dan P2 menunjukkan diameter porositas tulang yang cukup besar, akan tetapi tidak merata dan tidak sebanyak kelompok kontrol positif( $\mathrm{P} 0+)$, hal ini mungkin disebabkan karena proses remodeling tulang yang merupakan suatu siklus normal yang terjadi pada tulang dan berlangsung sepanjang hidup. Terlihat porositas terkecil ditunjukkan oleh tikus ovariohisterectomi dengan pemberian madu dosis 4 gram $/ \mathrm{Kg}$ BB (P3). Berdasarkan hasil pemeriksaan SEM ini maka dapat dinyatakan bahwa pemberian madu dengan dosis 4 gram $/ \mathrm{Kg}$ BB memilik efek anti Osteoporosis karena dapat menghambat penurunan kerusakan dan kepadatan tulang yang merupakan ciri dari tulang yang mengalami osteoporosis. Proses remodeling tulang merupakan pergantian jaringan tulang tua dengan jaringan tulang muda yang bertujuan untuk mempertahankan massa tulang (Berlianty, 2011). Proses remodeling tulang ini berlangsung secara bertahap pada bagian tertentu dari tulang, bagian-bagian atau jaringan yang mati dari fragmen-fragmen tulang secara berangsur-angsur diresorpsi oleh osteoklas. Dalam keadaaan normal, kecepatan resorpsi dan formasi tulang berlangsung dalam kecepatan yang sama sehingga massa tulang tetap konstan (Shombing, 2013).

Hasil penelitian ini membuktikan bahwa pemberian madu lebah (Apis dorsata) dapat mencegah terjadinya penurunan kepadatan tulang femur tikus putih ovariohisterektomi. Berdasarkan penelitian 
Zaid, et al. (2012), kandungan flavonoid pada madu Apis dorsata akan berinteraksi secara langsung dengan estrogen dapat meningkatkan absorpsi kalsium didalam usus. Flavonoid pada madu menginduksi RANKL pada reseptor $\mathrm{NF}-\kappa \mathrm{B}$ ligand dan osteoprotegerin (OPG) sehingga dapat mencegah terjadinya pengeroposan tulang (Brendan and Lianping, 2008). Proses resorbsi tulang dilakukan oleh osteoklas, sedangkan proses pembentukan tulang baru oleh osteoblas (Mariati, 2016). Kandungan lain dalam madu, seperti quarticetin dan kaempferol dapat menginduksi apoptosis osteoklas dewasa sehingga menghambat resorbsi tulang dan reactive oxygen species intraseluler dalam osteoklas (Sarah, et al., 2012), yang dapat mempengaruhi keseimbangan proses remodelling, yaitu ditandai dengan pembongkaran dan rekonstruksi bagian mikroskopis kalsifikasi matriks tulang (Ermanno, 2014), sehingga quarticetin dan kaempferol dalam madu memiliki efek positif terhadap massa tulang dan mencegah resobsi tulang oleh osteoklas (Mariati, 2016). Akhirnya terjadi keseimbangan antara resorpsi tulang lama dan formasi tulang baru yang menyebabkan kepadatan tulang tetap terjaga dan tidak terjadi kerusakan tulang (Shombing dkk, 2013).

\section{Kesimpulan}

Madu lebah (Apis dorsata) dapat mencegah penurunan kepadatan tulang femur yang dianalisis dengan menggunakan SEM (Scanning Electron Microscope).

\section{Ucapan Terima Kasih}

Terima kasih diucapkan kepada MenristekDikti yang telah mendanai penelitian ini melalui Dana Hibah Program Kreatifitas Mahasiswa 2017.

\section{Daftar Pustaka}

Afiyah, R. K. (2010). Kualitas Hidup Perempuan yang Mengalami Histerektomi serta Faktor-Faktor yang Mempengaruhinya di Wilayah DKI Jakarta : Study Grounded Theory. Jakarta: Universitas Indonesia.

Berlianty, A. (2011). Kajian Morfologi Proses Persembuhan Kerusakan Segmental pada Tulang Domba yang Diimplan dengan Komposit Hidroksipatit-Kitosan (HA-K). Bogor: Institut Pertanian Bogor.

Brendan and Lianping. (2008). Functions of RANKL/RANK/OPG in Bone Modeling and Remodeling. Archives of Biochemistry and Biophysics, 473(2): 139-146.

Ermanno and Paola. (2014). "Osteoporosis-Bone Remodeling and Animal Models." Tox. Path: 957-967.

Flecknell, P. (2009). Laboratory Animal Anaesthesia. Academic Press is an imprint of Elsevier Edition 3rd

Hadisoesilo, S. (2001). The Diversity of Indigenous Honey Bee Species of Indonesia. Biodiversitas vol 2. No. 1, 123-128.

Jaya, A. D. (2011). Manfaat Susu Kedelai-Madu Lokal Terhadap Ketebalan Tulang Kortikal (Compacta) dan Trabekular (Trabecular) Mandibula Tikus Wistar Jantan (Penelitian Eksperimental Laboratoris). Jember: Universitas Jember.

Mariati, N. (2016). Efek Pemberian Ekstrak Rumput Fatimah (Labisia pumila) terhadap Osteoklasin Serum dan Deoxypiridinolin Urin pada Tikus Post Ovariektomi. J. Kesehat Masy Indones, 1-8. htpp://jurnal.unimus.ac.id

Matthai, H.N., R. Appleyard, J. Jansen, J. Hao lin, S. Maastricht, M. Swain, R.S. Mason, C. Murrell, A.D. Diwan, T. Diamond. 2001. Osteoporosis Influences the Early Period of Fracture Healing in a Rat Osteoporotic Model. Bone. Vol 28: 1 .

Rachman, I. A. (2004). Manfaat Klinis Pengobatan Bifosfonat, dan Gabungan Bifosfonat dengan TSH Pada Osteoporosis Post Menopause Di Jakarta. Perosi, 1-13.

Sabri, M. (2013). Administration's Effects Of Ethanol Extract of Cissus Quadrangularis Salisb On Growth Of Lumbal Bone In Ovariectomized Rats. Jurnal Natural, Vol. 13, No. 2, hal. 4854. 
Sarah, S. M., Amrah, s., Hayati, \& Nor. (2012). Protective effects of Tualang honey on bone structure. Clinics, 779-784.

Shombing, I., Wangko, S., dan Sonny. (2013). Peran Estrogen Pada Remodeling Tulang. E.journal Universitas Sam Ratulangi, 18-30.

Syam, Y., D. Noersasongko, H. Sunaryo. (2014). Fraktur Akibat Osteoporosis. Jurnal e-CliniC, $2(2): 1-6$.

Utomo, M., Meikawati, W., Putri, Z.K. (2010). Faktor-Faktor yang Berhubungan dengan Kepadatan Tulang pada Wanita Postmenopause. J. Kesehat Masy Indones vol. 6 no. 2.htpp://jurnal.unimus.ac.id

Yudaniayanti, I.S., D. Galijono, and M.Z. Arifin. (2014). Potensi Ekstrak Cikal Tulang (Cissus Quadrangularis) Terhadap peningkatan Densitas dan Panjang Femur serta Perubahan Berat Badan Tikus Putih (Rattus norvegicus) Ovariektomi Sebagai Model Osteoporosis. Lap. Penelitian dana BOPTN
Yudi. (2011). yudiprasetyo53.wordpress.com. Dipetik 11 15, 2016, dari https://yudiprasetyo53.wordpress.com/2011/11/07/scanningelectron-microscope-sem-dan-opticalemission-spectroscope-oes/

Zaid, S.S., Sulaiman, S.A., Sirajudeen, K.N., Othman, N.H. (2010). The Effects of Tualang Honey on Female reproductive organs, tibia bone and hormonal profile in ovariectomised rats animal model for menopause. J Compl Altv Med. 10(82): 1-7.

Zaid, S.S.M., Sulaiman, S.A., Othman, N.H., Soelaiman, I.-N., Shuid, A.N., Mohamad, N. and Muhamad, N. (2012). Protective Effects of Tualang Honey on Bone Structure in Experimental Postmenopausal Rats. J Clinics. 67(7): 779-784. 